\title{
Geobacter hydrogenophilus, Geobacter chapellei and Geobacter grbiciae, three new, strictly anaerobic, dissimilatory Fe(III)-reducers
}

\author{
John D. Coates, ${ }^{1}$ Vishvesh K. Bhupathiraju, ${ }^{2}$ Laurie A. Achenbach, ${ }^{1}$ \\ Michael J. Mclnerney ${ }^{4}$ and Derek R. Lovley ${ }^{3}$
}

\footnotetext{
1 Department of Microbiology and Center for Systematic Biology, Southern Illinois University, Carbondale, IL 62901, USA

2 Department of Civil and Environmental Engineering, University of California, Berkeley, CA 94720, USA

3 Department of Microbiology, University of Massachusetts, Amherst MA 01003, USA

4 Department of Botany and Microbiology, University of Oklahoma, Norman, OK 73019, USA
}

Author for correspondence: John D. Coates. Tel: +1 618453 6132. Fax: + 16184538036. e-mail: jcoates@micro.siu.edu

\begin{abstract}
Recent studies on the diversity and ubiquity of Fe(III)-reducing organisms in different environments led to the isolation and identification of four new dissimilatory Fe(III)-reducers (strains $\mathrm{H}^{-2^{\top}}, \mathbf{1 7 2}^{\top}, \mathrm{TACP}^{-2^{\top}}$ and TACP-5). All four isolates are non-motile, Gram-negative, freshwater, mesophilic, strict anaerobes with morphology identical to that of Geobacter metallireducens strain GS-15'. Analysis of the 16S rRNA sequences indicated that the new isolates belong to the genus Geobacter, in the $\delta$-Proteobacteria. Significant differences in phenotypic characteristics, DNA-DNA homology and G+C content indicated that the four isolates represent three new species of the genus. The names Geobacter hydrogenophilus sp. nov. (strain $\mathbf{H - 2 ^ { \top }}$ ), Geobacter chapellei sp. nov. (strain 172') and Geobacter grbiciae sp. nov. (strains TACP-2 ${ }^{\top}$ and TACP-5) are proposed. Geobacter hydrogenophilus and Geobacter chapellei were isolated from a petroleum-contaminated aquifer and a pristine, deep, subsurface aquifer, respectively. Geobacter grbiciae was isolated from aquatic sediments. All of the isolates can obtain energy for growth by coupling the oxidation of acetate to the reduction of Fe(III). The four isolates also coupled $\mathrm{Fe}$ (III) reduction to the oxidation of other simple, volatile fatty acids. In addition, Geobacter hydrogenophilus and Geobacter grbiciae were able to oxidize aromatic compounds such as benzoate, whilst Geobacter grbiciae was also able to use the monoaromatic hydrocarbon toluene.
\end{abstract}

Keywords: Fe(III)-reduction, Geobacter, hydrocarbon oxidation, anaerobic

\section{INTRODUCTION}

In the last decade, microbial $\mathrm{Fe}(\mathrm{III})$ reduction has been identified as an important process in the mineralization of organic carbon in the environment (Lovley et al., 1997, and references therein). During this time, in excess of 40 micro-organisms have been isolated, characterized and identified that couple anaerobic growth to the respiration of Fe(III). Phylogenetically, these organisms are very diverse, including representatives from all subclasses of the Proteobacteria (Cummings et al., 1999; Lovley et al., 1997; and references therein) as well as those forming novel

The GenBank/EMBL/DDBJ accession numbers for the 16S rRNA sequences described in this work are AF335182 (strain TACP-2T), AF335183 (strain TACP-5), U28173 (strain $\mathrm{H}-2^{\top}$ ) and U41561 (strain $172^{\top}$ ). lines of descent in the domain Bacteria (Caccavo et al., 1996; Coates et al., 1999). In addition, a recent study demonstrated that the metabolic ability to grow by dissimilatory $\mathrm{Fe}(\mathrm{III})$ reduction is also found amongst the extreme thermophiles in the domain Archaea (Vargas et al., 1998).

Studies have shown that, of the known Fe(III)reducing bacteria, members of the genera Geothrix and Geobacter are the predominant Fe(III)-reducing bacteria found in most environments (Anderson et al., 1998; Coates et al., 1999). Both of these groups of organisms comprise strict anaerobes that oxidize organic matter completely to carbon dioxide (Coates \& Lovley, 2001; Coates et al., 1999; Lovley et al., 1997). Geothrix represents a novel line of descent in the Bacteria (Coates et al., 1999), whereas Geobacter species are members of the family Geobacteraceae in 
the $\delta$-Proteobacteria (Coates \& Lovley, 2001). Of the two genera, species of Geobacter are the most readily isolated, especially from hydrocarbon-contaminated environments and freshwater aquatic environments (Anderson et al., 1998; Coates \& Anderson, 2000; Coates et al., 1996, 1998; Lovley \& Coates, 2000; Lovley \& Phillips, 1988).

As part of a previous study on the diversity and ubiquity of $\mathrm{Fe}(\mathrm{III})$-reducing bacteria in the environment, several new $\mathrm{Fe}(\mathrm{III})$-reducing isolates were obtained (Coates et al., 1996). All of these isolates were strictly anaerobic, Gram-negative, non-motile rods with identical cell shapes and sizes. Phenotypic characterization of each of the isolates revealed that all were capable of oxidizing acetate completely with the concomitant reduction of Fe(III) (Coates et al., 1996). Analysis of the 16S rRNA gene sequences indicated that these organisms were all members of the family Geobacteraceae in the $\delta$-Proteobacteria. Although phenotypic characterization suggested that there were significant differences amongst the isolates, for three of them, the high degree of sequence similarity to Geobacter metallireducens made it unclear as to whether these isolates represented new species within the genus Geobacter. Here, we report the results of a more extensive analysis of 16S rDNA gene sequences as well as DNA-DNA homology and $\mathrm{G}+\mathrm{C}$ content analyses. These additional studies support the formation of three new species within the genus Geobacter.

\section{METHODS}

Sources of organisms. Strain $\mathrm{H}-2^{\mathrm{T}}$ was isolated as part of a study on the effects of $\mathrm{Fe}(\mathrm{III})$ chelators on the biodegradation of hydrocarbons under $\mathrm{Fe}(\mathrm{III})$-reducing conditions (Coates et al., 1996; Lovley et al., 1994). Strain $172^{\mathrm{T}}$ was isolated from acetate-oxidizing, $\mathrm{Fe}$ (III)-reducing enrichments of sediments collected from a deep aquifer of the Atlantic Plain in South Carolina, USA (Lovley et al., 1990). Strains TACP-2 ${ }^{\mathrm{T}}$ and TACP-5 were isolated from a freshwater aquatic sediment collected from the estuary of the Potomac River in Virginia, USA (Coates et al., 1996). Geobacter metallireducens strain GS-15 $5^{\mathrm{T}}$ and Geobacter sulfurreducens strain $\mathrm{PCA}^{\mathrm{T}}$ were obtained from our culture collection of dissimilatory Fe(III)-reducers. Desulfuromonas acetoxidans DSM $684^{\mathrm{T}}$ was obtained from the DSMZ (Braunschweig, Germany). All cultures were maintained in a frozen state at $-70{ }^{\circ} \mathrm{C}$ after the addition of $10 \%(\mathrm{v} / \mathrm{v})$ sterile glycerol to an actively growing culture.

Media and growth conditions. Standard anaerobic culture techniques were used throughout (Balch et al., 1979; Hungate, 1969; Miller \& Wolin, 1974). The medium was boiled under $\mathrm{N}_{2} / \mathrm{CO}_{2}(80: 20)$ to remove dissolved $\mathrm{O}_{2}$, dispensed into anaerobic pressure tubes or serum bottles under $\mathrm{N}_{2} / \mathrm{CO}_{2}$, capped with thick butyl-rubber stoppers and then sterilized by autoclaving. The basal medium was the bicarbonate-buffered freshwater medium that was used previously to culture Geobacter metallireducens (Lovley \& Phillips, 1988). Unless otherwise noted, acetate (10 mM) was the electron donor. Fumarate $(50 \mathrm{mM})$ was supplied as the sole electron acceptor and incubations were done at $30^{\circ} \mathrm{C}$.

16S rRNA gene sequencing and phylogenetic analysis. Cells from $1.5 \mathrm{ml}$ pure culture were harvested and lysed by being boiled in $40 \mu \mathrm{l}$ sterile water plus $5 \mu \mathrm{l}$ chloroform. Primers specific to the bacterial $16 \mathrm{~S}$ rRNA gene $\left(8 \mathrm{~F}, 5^{\prime}\right.$-AGAGTTTGATCCTGGCTCAG-3'; 1525R, 5'-AAGGAGGTGATCCAGCC-3') were used in a PCR that consisted of $10 \mathrm{mM}$ Tris $/ \mathrm{HCl}(\mathrm{pH} 9 \cdot 0), 50 \mathrm{mM} \mathrm{KCl}, 0 \cdot 1 \%$ Triton X-100, $1.2 \mathrm{mM}$ $\mathrm{MgCl}_{2}, 0.2 \mathrm{mM}$ each dNTP, $75 \mathrm{ng}$ each primer, $0.5 \mu \mathrm{Taq}$ polymerase (Gibco-BRL) and $1 \mu \mathrm{l}$ lysed cells in a $50 \mu \mathrm{l}$ reaction. Amplifications were performed as follows: $94^{\circ} \mathrm{C}$ for $3 \mathrm{~min}$, followed by 30 cycles of $94^{\circ} \mathrm{C}$ for $1 \mathrm{~min}, 55^{\circ} \mathrm{C}$ for $1 \mathrm{~min}$ and $72{ }^{\circ} \mathrm{C}$ for $2 \mathrm{~min}$, followed by a $10 \mathrm{~min}$ incubation at $72{ }^{\circ} \mathrm{C}$. Amplification products were gel-purified (GeneClean; Bio 101) and cycle-sequenced (ThermoSequenase; Amersham). Sequence entry and manipulation were performed with MACVECTOR 6.0 sequence-analysis software for the Macintosh (IBI). Sequences of selected 16S rRNA genes were obtained from the Ribosomal Database Project (Maidak et al., 1999) and GenBank (Benson et al., 2000) and were analysed by using the computer program SEQAPP (Gilbert, 1993). The 16S rRNA gene sequences from strains $\mathrm{H}-2^{\mathrm{T}}, 172^{\mathrm{T}}$, TACP-2 ${ }^{\mathrm{T}}$ and TACP-5 were aligned manually using secondary-structure information for proper alignment. Only those regions sequenced in all of the organisms (1052 nucleotides) were used in the phylogenetic analyses. Distance-matrix, parsimony and maximum-likelihood analyses of the aligned sequences were performed using PAUP* 4.0d65 (Swofford, 1999). Bootstrap analysis was conducted on 100 replications using a heuristic search strategy to assess the confidence level of various clades. The GenBank accession numbers for the sequences shown in Fig. 1 are as follows (in parentheses): Desulfuromonas acetexigens (U23140), Desulfuromonas acetoxidans (M26634), Desulfuromonas chloroethenica (U49748), Desulfuromonas palmitatis (U28172), Desulfuromonas thiophila (Y11560), Desulfomonile tiedjei (M26635), Desulfuromusa bakii (X79412), Desulfuromusa kysingii (X79414), Desulfuromusa succinoxidans (X79415), 'Geobacter akaganeitreducens' (U96918), 'Geobacter arculus' (U96917), Geobacter chapellei strain $172^{\mathrm{T}}$ (U41561), Geobacter grbiciae strain TACP-2 ${ }^{\mathrm{T}}$ (AF335182), Geobacter grbiciae strain TACP $-5^{\mathrm{T}}$ (AF335183), Geobacter hydrogenophilus strain $\mathrm{H}-2^{\mathrm{T}}$ (U28173), 'Geobacter humireducens' (AF019932), Geobacter metallireducens (L07834), Geobacter sulfurreducens (U13928), Pelobacter acetylenicus (X70955), Pelobacter acidigallici (X77216), Pelobacter carbinolicus (X79413), Pelobacter propionicus (X70954) and Pelobacter venetianus (U41562).

Determination of DNA base composition. DNA was isolated from cell pellets of the individual strains grown in basal medium with acetate as the electron donor $(10 \mathrm{mM})$. DNA isolation was performed using standard procedures (Marmur, 1961). The $\mathrm{G}+\mathrm{C}$ ratio was determined by using HPLC as described previously (Mesbah et al., 1989). Nonmethylated $\lambda$ DNA was used as the standard (Sigma).

DNA-DNA hybridization. DNA isolated from the four new isolates, Geobacter metallireducens, Geobacter sulfurreducens and $D$. acetoxidans was nick-translated with ${ }^{32} \mathrm{P}$-labelled dCTP by using a nick translation kit (Boehringer Mannheim) according to the manufacturer's specifications. Labelled DNA preparations were purified with Quick Spin columns (Boehringer Mannheim) and repeated ethanolprecipitation. DNA-DNA reassociation was performed by the free-solution method and analysed by means of the S1nuclease procedure, as described previously (Johnson, 1994). Reassociation mixtures contained $12.5 \%$ formamide. Reassociation was performed at $47^{\circ} \mathrm{C}$. 


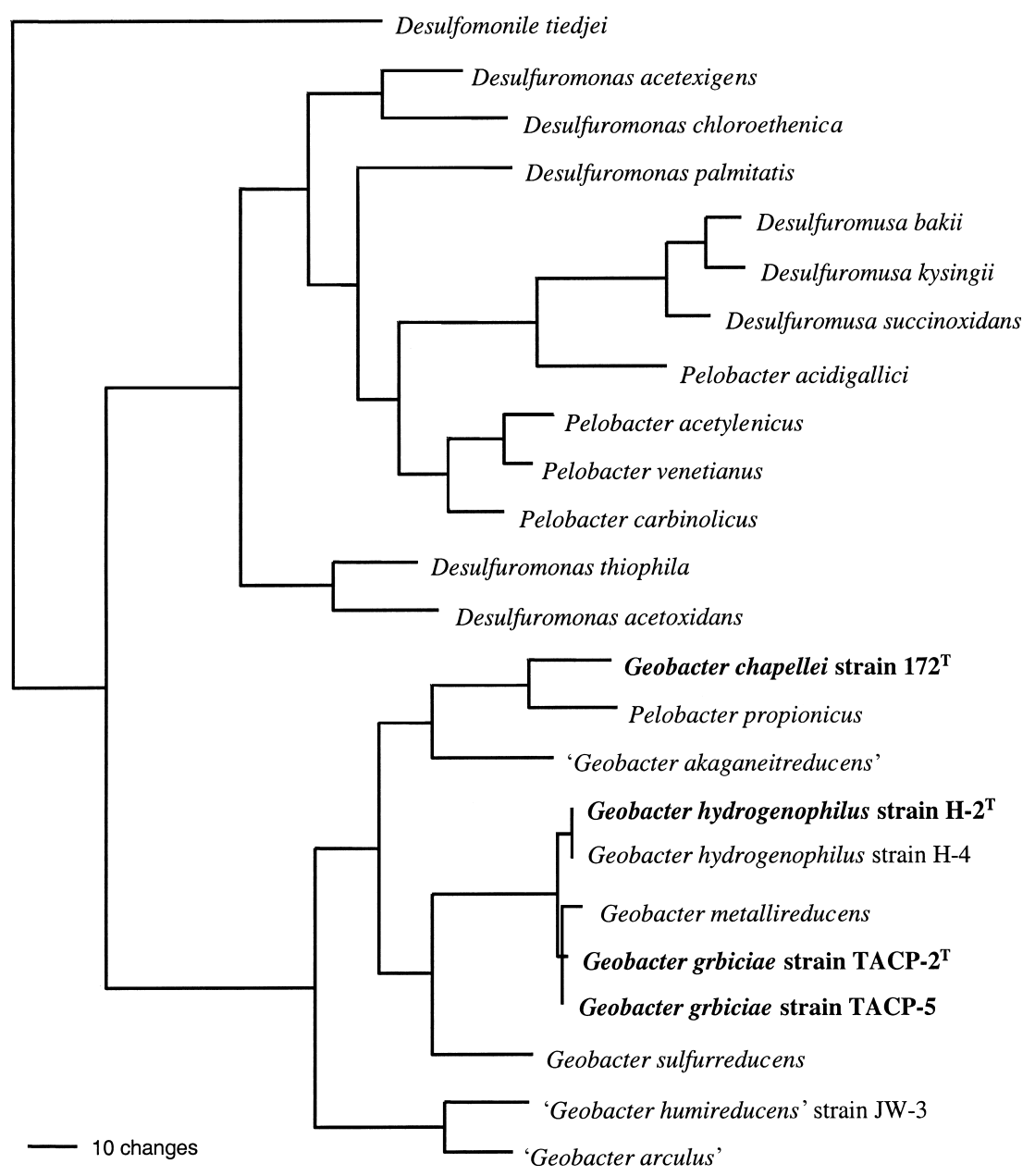

Fig. 1. Phylogenetic tree of the $16 \mathrm{~S}$ rDNA sequence dataset resulting from parsimony analysis. Branch lengths are from a branch-and-bound analysis. Tree length, 722 ; consistency index minus uninformative sites, $0.504 ;$ retention index, 0.722. Bar, 10 changes.

\section{RESULTS}

Strains $\mathrm{H}-2^{\mathrm{T}}, 172^{\mathrm{T}}$, TACP-2 $2^{\mathrm{T}}$ and TACP-5 were all Gram-negative, non-motile, non-fermenting, nonspore-forming, strict anaerobes (Coates et al., 1996). All of the strains were morphologically identical (Coates et al., 1996). In addition, all of the strains coupled the complete oxidation of organic carbon compounds to the reduction of Fe(III) (Coates et al., 1996). Phenotypic and morphological characterization demonstrated that the characteristics were most similar to those of Geobacter metallireducens strain GS$15^{\mathrm{T}}$, the type species of the genus Geobacter (Lovley et al., 1993) within the family Geobacteraceae (see Table 3).

\section{Analyses of the 16S rRNA gene sequence}

Analysis of the almost complete sequences of the 16S rRNA genes of all of the strains revealed that the four new isolates were related to members of the genus Geobacter in the $\delta$-Proteobacteria (Fig. 1). The $16 \mathrm{~S}$
rRNA gene sequence of strain $172^{\mathrm{T}}$ differed from those of other described Geobacter species and from those of strains $\mathrm{H}-2^{\mathrm{T}}$, TACP $-2^{\mathrm{T}}$ and TACP- 5 by more than $5 \%$ (Table 1). Strain $172^{\mathrm{T}}$ appears to be most closely related to $P$. propionicus $(3.4 \%$ difference), which is also a member of the Geobacteraceae. The 16S rRNA gene sequences of strains $\mathrm{H}-2^{\mathrm{T}}$, TACP- $2^{\mathrm{T}}$ and TACP5 were closely related to each other (distance values ranged from 0.097 to $0.49 \%$ ) and to that of Geobacter metallireducens strain GS- $15^{\mathrm{T}}$ (distance values ranged from 0.39 to $0.78 \%$ ). The close similarity between the 16S rRNA gene sequences of strains $\mathrm{H}-2^{\mathrm{T}}$, TACP- $2^{\mathrm{T}}$ and TACP-5 and Geobacter metallireducens renders speciation based on 16S rRNA gene sequences alone ambiguous.

\section{DNA base composition}

The $\mathrm{G}+\mathrm{C}$ content of DNA from strain $172^{\mathrm{T}}$ was $50 \cdot 2 \mathrm{~mol} \%$, which is markedly different from that of the other species in the genus Geobacter (Table 2) and 
Table 1 Evolutionary distance matrix of $16 \mathrm{~S}$ rDNA sequences, including strains $\mathrm{H}-2^{\top}, 172^{\top}$, TACP- $^{\top}$ and TACP-5

\begin{tabular}{|c|c|c|c|c|c|c|c|c|}
\hline Taxon & 1 & 2 & 3 & 4 & 5 & 6 & 7 & 8 \\
\hline 1. Strain $\mathrm{H}-2^{\mathrm{T}}$ & & & & & & & & \\
\hline 2. Strain $172^{\mathrm{T}}$ & $5 \cdot 3$ & & & & & & & \\
\hline 3. Strain TACP- $2^{\mathrm{T}}$ & $0 \cdot 49$ & $5 \cdot 5$ & & & & & & \\
\hline 4. Strain TACP-5 & $0 \cdot 39$ & $5 \cdot 4$ & $0 \cdot 097$ & & & & & \\
\hline 5. Geobacter metallireducens & 0.78 & $5 \cdot 7$ & $0 \cdot 49$ & $0 \cdot 39$ & & & & \\
\hline 6. 'Geobacter akaganeitreducens' & $5 \cdot 8$ & $5 \cdot 3$ & $6 \cdot 0$ & $5 \cdot 9$ & $6 \cdot 2$ & & & \\
\hline 7. Pelobacter propionicus & $6 \cdot 7$ & $3 \cdot 4$ & $6 \cdot 6$ & $6 \cdot 5$ & $6 \cdot 8$ & $6 \cdot 0$ & & \\
\hline 8. Geobacter sulfurreducens & $4 \cdot 6$ & $6 \cdot 3$ & $4 \cdot 6$ & $4 \cdot 5$ & $4 \cdot 8$ & $5 \cdot 7$ & $5 \cdot 8$ & \\
\hline 9. 'Geobacter humireducens' & $6 \cdot 8$ & $6 \cdot 7$ & $6 \cdot 8$ & $6 \cdot 7$ & $7 \cdot 0$ & $6 \cdot 7$ & $7 \cdot 3$ & $6 \cdot 8$ \\
\hline
\end{tabular}

Table 2 DNA base composition and levels of DNA-DNA homology between strains $\mathrm{H}-2^{\top}, 172^{\top}$, TACP- $^{\top}$, TACP-5 and related bacteria

\begin{tabular}{|c|c|c|c|c|}
\hline \multirow[t]{2}{*}{ Taxon } & \multirow{2}{*}{$\begin{array}{c}G+C \text { content } \\
(\mathrm{mol} \%)\end{array}$} & \multicolumn{3}{|c|}{ DNA hybridization ( $\%$ ) with ${ }^{32}$ P-labelled DNA from: } \\
\hline & & Strain $\mathbf{H}-2^{\mathrm{T}}$ & Strain $172^{\mathrm{T}}$ & Strain TACP-2 ${ }^{\mathrm{T}}$ \\
\hline Geobacter metallireducens & $58 \cdot 9 \pm 0 \cdot 3$ & 54 & 30 & 30 \\
\hline Geobacter sulfurreducens & $60 \cdot 6 \pm 0 \cdot 4$ & 26 & 32 & 46 \\
\hline Desulfuromonas acetoxidans & $52 \cdot 2 \pm 0 \cdot 3$ & 13 & 33 & 22 \\
\hline Strain $\mathrm{H}-2^{\mathrm{T}}$ & $58 \cdot 4 \pm 0 \cdot 2$ & 100 & 15 & 40 \\
\hline Strain $172^{\mathrm{T}}$ & $50 \cdot 2 \pm 0 \cdot 3$ & 14 & 100 & 35 \\
\hline Strain TACP-2 $2^{\mathrm{T}}$ & $57 \cdot 4 \pm 0 \cdot 3$ & 43 & 18 & 100 \\
\hline Strain TACP-5 & $57 \cdot 3 \pm 0 \cdot 2$ & 39 & 20 & 86 \\
\hline
\end{tabular}

is consistent with the analysis of the $16 \mathrm{~S}$ rRNA gene sequence information. The values for strain $\mathrm{H}-2^{\mathrm{T}}$ and Geobacter metallireducens were almost identical (Table 2 ), supporting their close phylogenetic relationship. The $\mathrm{G}+\mathrm{C}$ contents of strains TACP- $2^{\mathrm{T}}$ and TACP-5 were also almost identical to each other, but differed from that of Geobacter metallireducens by $1.5 \%$ and from that of strain $\mathrm{H}-2^{\mathrm{T}}$ by about $1 \%$. It should be noted that, although the $\mathrm{G}+\mathrm{C}$ content determined here for D. acetoxidans was similar to values published previously (Finster et al., 1997), the value obtained for Geobacter metallireducens strain GS-15 $5^{\mathrm{T}}$ was slightly higher than that published previously. This difference was probably a function of the different method employed in this study (HPLC, as opposed to the thermal denaturation method employed previously by Lovley et al., 1993).

\section{DNA-DNA hybridization}

In support of the close similarities in the $16 \mathrm{~S}$ rRNA gene sequences and $\mathrm{G}+\mathrm{C}$ content, there was also a high percentage of DNA-DNA homology between strains TACP-2 ${ }^{\mathrm{T}}$ and TACP-5 (86\%). Little or no DNA-DNA homology was observed between strain TACP $-2^{\mathrm{T}}$ and any of the other tested members of the genus Geobacter, which suggests that these two organisms are representative strains of the same species within the genus Geobacter. Strains $172^{\mathrm{T}}$ and $\mathrm{H}-2^{\mathrm{T}}$ exhibited little or no DNA-DNA homology with each other or with any other organisms tested, suggesting that these strains each represent new species in the genus Geobacter.

\section{DISCUSSION}

Previous phenotypic characterization studies (Coates et al., 1996) of strains $\mathrm{H}-2^{\mathrm{T}}, 172^{\mathrm{T}}$, TACP-2 ${ }^{\mathrm{T}}$ and TACP-5 (Table 3) demonstrated that all of the strains were similar to many species of the known genera in the family Geobacteraceae; however, incomplete genotypic analysis rendered taxonomic description of these organisms ambiguous. The genotypic analyses presented in this study suggest that significant differences exist between these strains and previously described $\mathrm{Fe}(\mathrm{III})$-reducing bacteria. The analysis of $16 \mathrm{~S}$ rRNA gene sequences and DNA-DNA hybridization studies further support the general conclusion that strains with 16S rRNA gene-sequence similarities of less than $97 \%$ do not exhibit DNA-DNA homologies of $70 \%$ or more (Stackebrandt \& Goebel, 1994). It is also interesting to note that organisms such as strain TACP- $2^{\mathrm{T}}$ and Geobacter metallireducens, which have greater than $99 \%$ similarity in terms of $16 \mathrm{~S}$ rRNA gene sequence, exhibit DNA-DNA homology of only $30 \%$, which is well below the minimum percentage 
Table 3 Phenotypic differences amongst strains $\mathrm{H}-2^{\top}, 172^{\top}, \mathrm{TACP}-2^{\top}$ and TACP-5 and related bacteria

The properties of strain TACP-5 were identical to those listed for strain TACP-2 ${ }^{\mathrm{T}}$. Abbreviations: AQDS, 2,6-Anthraquinone disulfonate, a humic-substance analogue; $G$., Geobacter.

\begin{tabular}{|c|c|c|c|c|c|}
\hline Character & G. metallireducens $\mathrm{GS}-15^{\mathrm{T}}$ & G. hydrogenophilus $\mathrm{H}-2^{\mathrm{T}}$ & G. grbiciae ТАCP-2 $^{\mathrm{T}}$ & G. sulfurreducens & G. chapellei $172^{\mathrm{T}}$ \\
\hline Source & Aquatic sediments & Contaminated aquifer & Aquatic sediments & Contaminated ditch & Deep subsurface sediments \\
\hline \multicolumn{6}{|l|}{$\begin{array}{l}\text { Electron donors } \\
\text { oxidized with } \mathrm{Fe}(\mathrm{III}) \text { : }\end{array}$} \\
\hline $\mathrm{H}_{2}$ & No & Yes & Yes & Yes & No \\
\hline Formate & No & Yes & Yes & No & Yes \\
\hline Acetate & Yes & Yes & Yes & Yes & Yes \\
\hline Propionate & Yes & Yes & Yes & No & No \\
\hline Ethanol & Yes & Yes & Yes & No & Yes \\
\hline Lactate & No & No & No & No & Yes \\
\hline Benzoate & Yes & Yes & Yes & No & No \\
\hline $\begin{array}{l}\text { Other electron } \\
\text { donors used }\end{array}$ & $\begin{array}{l}\text { Butyrate, valerate, } \\
\text { isovalerate, toluene, } \\
\text { phenol, } p \text {-cresol, } \\
\text { benzaldehyde, pyruvate }\end{array}$ & $\begin{array}{l}\text { Butyrate, pyruvate, } \\
\text { succinate }\end{array}$ & $\begin{array}{l}\text { Toluene, pyruvate, } \\
\text { butyrate }\end{array}$ & None & None \\
\hline Electron acceptors & $\begin{array}{l}\text { Mn(IV), nitrate, U(VI), } \\
\text { AQDS, humic substances }\end{array}$ & Fumarate, U(VI) & AQDS & $\begin{array}{l}\mathrm{S}^{0}, \text { fumarate, } \\
\text { malate, } \mathrm{Co}(\mathrm{III})\end{array}$ & Mn(IV), U(VI), fumarate \\
\hline
\end{tabular}


homology $(70 \%)$ required for two strains to be accepted as being representatives of a single species (Johnson, 1994).

\section{Taxomonic status of strain $172^{\top}$}

On the basis of physiological differences with respect to other described Fe(III)-reducing bacteria (Table 3) and a low level of $16 \mathrm{~S}$ rRNA sequence similarity, strain $172^{\mathrm{T}}$ was recently described as a new species of the genus Geobacter (Coates et al., 1996; Lonergan et al., 1996) and was tentatively named Geobacter chapellei. The facts that strain $172^{\mathrm{T}}$ exhibited very low levels of DNA-DNA homology with the other organisms examined in this study and that it had significantly lower $\mathrm{G}+\mathrm{C}$ content than other Fe(III)reducers confirm this conclusion. It is proposed that strain $172^{\mathrm{T}}$ is the type strain of a new species, Geobacter chapellei sp. nov. In contrast to other Fe(III)-reducing bacteria, Geobacter chapellei cannot use Fe(III) chelated with citrate as an electron acceptor.

\section{Taxonomic status of strain $\mathbf{H}-2^{\top}$}

In addition to having similar morphologies, strain $\mathrm{H}$ $2^{\mathrm{T}}$ and Geobacter metallireducens also have several similar phenotypic traits. Both organisms oxidize simple fatty acids and aromatic compounds coupled to $\mathrm{Fe}$ (III) reduction (Coates et al., 1996; Lovley et al., 1993 ) and reduce $S^{0}$, although $S^{0}$ reduction does not provide energy to support the growth of either organism (Coates et al., 1996). Although there was a high degree of $16 \mathrm{~S}$ rDNA sequence similarity between Geobacter metallireducens and strain $\mathrm{H}-2^{\mathrm{T}}$, other significant physiological differences (Table 3 ) led to the suggestion that these organisms were, in fact, different species (Coates et al., 1996; Lonergan et al., 1996). The low DNA-DNA homology between strain $\mathrm{H}-2^{\mathrm{T}}$ and the other Geobacter species tested shows that strain $\mathrm{H}-$ $2^{\mathrm{T}}$ represents a new species in the genus Geobacter. In view of the ability of this strain to use $\mathrm{H}_{2}$ (Coates et al., 1996), the species name Geobacter hydrogenophilus sp. nov. is proposed.

\section{Taxonomic status of strains TACP-2 ${ }^{\top}$ and TACP-5}

Strains TACP-2 ${ }^{\mathrm{T}}$ and TACP-5 are almost identical morphologically, phylogenetically and in DNA base composition; only slight phenotypic differences are observed between the two strains (Coates et al., 1996), which suggests that they are representatives of the same species. Although there is a high degree of similarity between Geobacter metallireducens and these strains, both physiologically and in terms of $16 \mathrm{~S}$ rRNA gene sequence, the low DNA-DNA homology that exists between strain TACP-2 ${ }^{\mathrm{T}}$ and Geobacter metallireducens suggests that strains TACP- $2^{\mathrm{T}}$ and TACP-5 represent a different species from Geobacter metallireducens. On the basis of DNA-DNA homology studies, we propose that strains TACP- $2^{\mathrm{T}}$ and TACP-
5 are two representative strains of a new species in the genus Geobacter, Geobacter grbiciae sp. nov.

\section{Description of Geobacter chapellei sp. nov.}

Geobacter chapellei (cha.pel'le.i. N.L. gen. masc. n. chapellei of Chapelle, named after Frank Chapelle, who contributed to our knowledge of subsurface biogeochemistry).

Rod-shaped, non-motile, Gram-negative bacterium with cell dimensions of $1-2 \times 0 \cdot 6 \mu \mathrm{m}$. Does not form spores. Strictly anaerobic chemo-organotroph that oxidizes acetate with the concomitant reduction of $\mathrm{Fe}(\mathrm{III})$. Other electron donors used in addition to acetate include ethanol, lactate and formate. Electron acceptors used include Fe(III), Mn(IV), fumarate and the humic-substance analogue 2,6-anthraquinone disulfonate; it does not use $\mathrm{Fe}(\mathrm{III})$ chelated with citrate. Whole-cell suspensions reduce U(VI), although it is not known whether this type of metabolism can supply energy for growth. Geobacter chapellei is redox sensitive and its growth rate is improved significantly by the presence of a reducing agent, such as Fe(II), in the medium. The cells contain $c$-type cytochromes. The optimum temperature for growth is $25^{\circ} \mathrm{C}$. Geobacter chapellei strain $172^{\mathrm{T}}$ was obtained from $\mathrm{Fe}(\mathrm{III})$ reducing enrichments of subsamples from deep aquifer sediments of the Atlantic Coastal Plain in South Carolina, USA. The type strain is strain $172^{\mathrm{T}}$ $\left(=\right.$ ATCC $51744^{\mathrm{T}}=$ DSM $\left.13688^{\mathrm{T}}\right)$.

\section{Description of Geobacter hydrogenophilus sp. nov.}

Geobacter hydrogenophilus (hy.dro.ge.no'phi.lus. N.L. $\mathrm{n}$. hydrogenium hydrogen; Gr. adj. philos friendly to; N.L. adj. hydrogenophilus liking hydrogen, referring to the ability of the organism to grow by oxidation of hydrogen).

Non-motile, non-spore-forming, rod-shaped, Gramnegative organism with cell dimensions of 1 $2 \times 0.6 \mu \mathrm{m}$. A strictly anaerobic chemo-organotroph that oxidizes acetate, formate, propionate, butyrate, ethanol, pyruvate, succinate and benzoate with the concomitant reduction of $\mathrm{Fe}(\mathrm{III})$. It also grows by the oxidation of $\mathrm{H}_{2}$ with the reduction of $\mathrm{Fe}(\mathrm{III})$ when citrate is provided as a carbon source. Growth is also possible with fumarate or the humic-substance analogue 2,6-anthraquinone disulfonate as the electron acceptor. $S^{0}$ is reduced, but $S^{0}$ reduction does not yield energy to support growth. Cell suspensions reduce $\mathrm{U}(\mathrm{VI})$. The temperature and $\mathrm{pH}$ optima are $35^{\circ} \mathrm{C}$ and 6.5. Geobacter hydrogenophilus can grow in medium containing $1 \%(\mathrm{w} / \mathrm{v}) \mathrm{NaCl}$, but grows optimally in freshwater medium. The cells contain $c$-type cytochromes. Geobacter hydrogenophilus was enriched from samples taken from a hydrocarbon-contaminated aquifer at the Defense Fuel Supply Center, Hanahan, SC, USA, using acetate as the electron donor and $\mathrm{Fe}(\mathrm{III})$-nitrilotriacetic acid as the electron 
acceptor. The type strain is strain $\mathrm{H}-2^{\mathrm{T}}$ (= ATCC $51590^{\mathrm{T}}=$ DSM $\left.13691^{\mathrm{T}}\right)$.

\section{Description of Geobacter grbiciae sp. nov.}

Geobacter grbiciae (grb.i'ci.ae. N.L. gen. fem. n. grbiciae of Grbic, named in honour of Dunja GrbicGalic for her significant contributions to the field of anaerobic aromatic hydrocarbon oxidation).

Cells are rod-shaped, Gram-negative, $1-2 \times 0.6 \mu \mathrm{m}$, non-motile and do not form spores. Strictly anaerobic chemo-organotroph that oxidizes acetate and other simple fatty acids or ethanol with the concomitant reduction of $\mathrm{Fe}(\mathrm{III})$. Strain TACP-5 can also oxidize monoaromatic compounds, including toluene, as alternative electron donors. Strain TACP-5 can use $\mathrm{H}_{2}$. Strain TACP-2 ${ }^{\mathrm{T}}$ can be grown with the various forms of soluble $\mathrm{Fe}(\mathrm{III})$ as well as with poorly crystalline $\mathrm{Fe}(\mathrm{III})$ oxide. In contrast, strain TACP-5 does not grow with $\mathrm{Fe}(\mathrm{III})$ chelated with citrate. Strains TACP-2 ${ }^{\mathrm{T}}$ and TACP-5 were isolated from freshwater aquatic sediment taken from the estuary of the Potomac River in Virginia, USA, at the same site that previously yielded Geobacter metallireducens. The type strain is strain TACP-2 $2^{\mathrm{T}}\left(=\mathrm{ATCC}\right.$ BAA- $-45^{\mathrm{T}}=$ DSM $\left.13689^{\mathrm{T}}\right)$. Strain TACP-5 $(=$ ATCC BAA-46 = DSM 13690) is a reference strain.

\section{ACKNOWLEDGEMENTS}

Support for J.D.C. was provided, in part, by grant $98 \mathrm{I}-13$ from the Illinois Council on Food and Agriculture Research and for J.D.C. and L.A.A. by the Department of Energy (grant number DE-FG02-98ER62689). Support for D. R.L. was provided by the Department of Energy (grant number DE-FG02-97ER62475).

\section{REFERENCES}

Anderson, R. T., Rooney-Varga, J. N., Gaw, C. V. \& Lovley, D. R. (1998). Anaerobic benzene oxidation in the Fe(III) reduction zone of petroleum-contaminated aquifers. Environ Sci Technol 32, 1222-1229.

Balch, W. E., Fox, G. E., Magrum, L. J., Woese, C. R. \& Wolfe, R. S. (1979). Methanogens: reevaluation of a unique biological group. Microbiol Rev 43, 260-296.

Benson, D. A., Karsch-Mizrachi, I., Lipman, D. J., Ostell, J., Rapp, B. A. \& Wheeler, D. L. (2000). GenBank. Nucleic Acids Res 28, $15-18$.

Caccavo, F., Jr, Coates, J. D., Rossello-Mora, R. A., Ludwig, W., Schleifer, K. H., Lovley, D. R. \& McInerney, M. J. (1996). Geovibrio ferrireducens, a phylogenetically distinct dissimilatory $\mathrm{Fe}(\mathrm{III})-$ reducing bacterium. Arch Microbiol 165, 370-376.

Coates, J. D. \& Anderson, R. T. (2000). Emerging techniques for anaerobic bioremediation of contaminated environments. Trends Biotechnol 18, 408-412.

Coates, J. D. \& Lovley, D. R. (2001). Family Geobacteraceae. In Bergey's Manual of Systematic Bacteriology, 2nd edn. Edited by G. M. Garrity. New York: Springer (in press).

Coates, J. D., Phillips, E. J. P., Lonergan, D. J., Jenter, H. \& Lovley, D. R. (1996). Isolation of Geobacter species from diverse sedimentary environments. Appl Environ Microbiol 62, 1531-1536.
Coates, J. D., Ellis, D. J., Blunt-Harris, E. L., Gaw, C. V., Roden, E. E. \& Lovley, D. R. (1998). Recovery of humic-reducing bacteria from a diversity of environments. Appl Environ Microbiol 64, 1504-1509.

Coates, J. D., Ellis, D. J., Gaw, C. V. \& Lovley, D. R. (1999). Geothrix fermentans gen. nov., sp. nov., a novel Fe(III)-reducing bacterium from a hydrocarbon-contaminated aquifer. Int J Syst Bacteriol 49, 1615-1622.

Cummings, D. E., Caccavo, F., Jr., Spring, S. \& Rosenzweig, R. F. (1999). Ferribacterium limneticum, gen. nov., sp. nov., an $\mathrm{Fe}(\mathrm{III})$-reducing microorganism isolated from mining-impacted freshwater lake sediments. Arch Microbiol 171, 183-188.

Finster, K., Coates, J. D., Liesack, W. \& Pfennig, N. (1997). Desulfuromonas thiophila sp. nov., a new obligately sulfurreducing bacterium from anoxic freshwater sediment. Int $J$ Syst Bacteriol 47, 754-758.

Gilbert, D. G. (1993). SEQAPP 1.9a157. Biocomputing Office, Biology Dept, Indiana University, Bloomington, IN, USA.

Hungate, R. E. (1969). A roll-tube method for cultivation of strict anaerobes. Methods Microbiol 3B, 117-132.

Johnson, J. L. (1994). Similarity analysis of DNA. In Methods for General and Molecular Bacteriology, pp. 655-682. Edited by P. Gerhardt, R. G. E. Murray, W. A. Wood \& N. R. Krieg. Washington, DC: American Society for Microbiology.

Lonergan, D. J., Jenter, H. L., Coates, J. D., Schmidt, T. M. \& Lovley, D. R. (1996). Phylogenetic analysis of dissimilatory Fe(III)-reducing bacteria. J Bacteriol 178, 2402-2408.

Lovley, D. R. \& Coates, J. D. (2000). Novel forms of anaerobic respiration of environmental relevance. Curr Opin Microbiol 3, 252-256.

Lovley, D. R. \& Phillips, E. J. P. (1988). Novel mode of microbial energy metabolism: organic carbon oxidation coupled to dissimilatory reduction of iron or manganese. Appl Environ Microbiol 54, 1472-1480.

Lovley, D. R., Chapelle, F. H. \& Phillips, E. J. P. (1990). Fe(III)reducing bacteria in deeply buried sediments of the Atlantic Coastal Plain. Geology 18, 954-957.

Lovley, D. R., Giovannoni, S. J., White, D. C., Champine, J. E., Phillips, E. J. P., Gorby, Y. A. \& Goodwin, S. (1993). Geobacter metallireducens gen. nov. sp. nov., a microorganism capable of coupling the complete oxidation of organic compounds to the reduction of iron and other metals. Arch Microbiol 159, 336-344.

Lovley, D. R., Woodward, J. C. \& Chapelle, F. H. (1994). Stimulated anoxic biodegradation of aromatic hydrocarbons using Fe(III) ligands. Nature 370, 128-131.

Lovley, D. R., Coates, J. D., Saffarini, D. \& Lonergan, D. J. (1997). Diversity of dissimilatory $\mathrm{Fe}(\mathrm{III})$-reducing bacteria. In Transition Metals in Microbial Metabolism. Edited by G. Winkelmann \& C. J. Carrano. Lausanne, Switzerland: Harwood Academic.

Maidak, B. L., Cole, J. R., Parker, C. T., Jr \& 11 other authors (1999). A new version of the RDP (Ribosomal Database Project). Nucleic Acids Res 27, 171-173.

Marmur, J. (1961). A procedure for the isolation of deoxyribonucleic acid from microorganisms. J Mol Biol 3, 208-218.

Mesbah, M., Premachandran, U. \& Whitman, W. B. (1989). Precise measurement of the $\mathrm{G}+\mathrm{C}$ content of deoxyribonucleic acid by high-performance liquid chromatography. Int $J$ Syst Bacteriol 39, 159-167.

Miller, T. L. \& Wolin, M. J. (1974). A serum bottle modification of 
the Hungate technique for cultivating obligate anaerobes. Appl Microbiol 27, 985-987.

Stackebrandt, E. \& Goebel, B. M. (1994). Taxonomic note: a place for DNA-DNA reassociation and 16S rRNA sequence analysis in the present species definition in bacteriology. Int $J$ Syst Bacteriol 44, 846-849.
Swofford, D. L. (1999). PAUP*: phylogenetic analysis using parsimony (and other methods), version 4.0. Sunderland, MA: Sinauer Associates.

Vargas, M., Kashefi, K., Blunt-Harris, E. L. \& Lovley, D. R. (1998). Microbiological evidence for Fe(III) reduction on early Earth. Nature 395, 65-67. 